Covered in: ERIH PLUS, HeinOnline, CEEOL, Index Copernicus, CrossRef, CrossCheck, J-GATE, Google Scholar, Ideas RePeC, Econpapers, Socionet, KVK, WorldCat.

\section{„Jus” (Law) and „Justitia” (Justice) in Roman Solicitors' Perception and Definition. Reflections and Evaluations}

\section{Nicolae V. DURĂ ${ }^{1}$}

${ }^{1}$ Ovidius University of Constanta, Constanta, Romania, nicolaedidimos@yahoo.com

\begin{abstract}
In the Romanian specialized literature the two notions, „Jus" (Law) and „Justitia” (Justice), are commonly used and explained only from the contemporary legal expert's perspective, who - more often than not - does not always prove to be familiarized with not just „Jus romanum antiquum" (Old Roman law), and, ipso facto, the thinking of the famous Roman solicitors, but also with the history and philosophy of Roman Law. For this reason, in the pages of my paper I searched that, by presenting some relevant aspects of its content, to offer to its readers the possibility of revisiting the text of the „Old Roman law” (Jus romanum antiquum), and "ipso facto", to underline also the mode in which this Law was perceived and received in the landscape of Romanian legal thinking.

Consequently, with the intention of making a clarifying contribution regarding the evolutionary process of the ideational content of the two notions, "Jus" and "Justitia", in the pages of our study, with an interdisciplinary character, we have brought the reader, volens-nolens, ,ad fontes", that is to the sources of the Roman Law, in which we could find out not only their content and subjects, but also the definitions of the Roman solicitors about ,Jus" and ,Justitia".
\end{abstract}

Keywords: Fontes juris romanum; the philosophy of Roman law; Roman solicitors; Romanian legal thinking.

How to cite: Dură, N.V. (2019). "Jus" (Law) and "Justitia" (Justice) in Roman Solicitors' Perception and Definition. Reflections and Evaluations. Logos Universality Mentality Education Novelty: Law, 7(2), 45-56. doi:10.18662/lumenlaw/26 
„Jus” (Law) and „Justitia” (Justice) in Roman Solicitors' Perception and ... Nicolae V. DURĂ

\section{Introduction}

In the 2nd - 3rd centuries AD, the Roman Empire offered mankind a true conceptual (doctrinal) system regarding law and its nature, which has remained unmatched to this today due to the contribution made by some famous legal experts, such as, Celsus, Gaius, Julianus, Ulpianus, Modestinus etc.

Their works - in which the logic of legal reasoning goes hand in hand with the philosophy of Law - became, in fact, a source of law, known in the specialized literature as "Jus romanum antiquum" (Old Roman law) or "Jurisprudentiae" (Sayings or Pronunciations about Law), that is, about its ontology (being), nature, purpose etc.

Old sources of Law - due to these famous Roman legal experts, such as Gaius (130-180), who published a work entitled "Institutiones" (Institutions), and Julianus (110-170), who composed a work in 90 books entitled "Digestae" (Digests), - were kept for us and transmitted due to the two works published - under the same title - by Emperor Justinian's legal experts (527-565), led by the illustrious professor Tribonian at the Faculty of Law of the first Christian University in the Roman Empire, i.e. Constantinople (Dură, 2007).

Of course, we are referring to "Digestae" (Digests), published in 533, and "Institutiones" (Institutions), published in 534, both attributed, however, to Emperor Justinian.

The first work, which is, in fact, a Treaty of Roman Law, was drafted by a Commission of Roman legal experts, which included five law professors from Constantinople and Beirut and 11 lawyers from the Eastern District Court (Pereterskii, 1958). And, the second one, "Institutiones" (The Institutions), were a "handbook" ("Justiniani Institutiones", 2002) for the use of the students of the faculty of Law, drafted by the same professors of law at the solicitude of the last Roman Emperor, Justinian (527-565).

In the specialized literature, members of the commission - chaired by Tribonian - were called "compilatores" (Pereterskii, 1958) (compilers), but not within the meaning of today's term, i.e., "compilation authors", who would compile a paper "without a personal contribution" (DEX, 1998), but because they performed a work of compilation, selection and gathering of the opinions expressed by famous Roman legal experts from the classical era, about "jus" (law), "iustitia" (justice) etc. 


\section{The Perception of "Jus" from the period of "Jus Romanum antiquum" until to "Jus romanum novum" created by the emperor Justinian and his jurists}

In their references to the old texts, and, ipso facto, their reproductions from the text of the old sources, they did not limit themselves only to the intention of saving the text transmitted by "Jus vetus" (old law), that is, a large part of the Roman legal thinking heritage, but they completed and explained it "in eadem substantia", which they adapted to the demands of their time, thus laying the foundation for that "Jus romanum novum", created by none other than Emperor Justinian and his legal experts.

Therefore, Justinian's Institutions and Digests may only be considered a compilation insofar as we consider the fact that these authors have taken over and reproduced "ad litteram" various opinions, views and sayings of Roman legal experts from the classical era on Law, Justice, Jurisprudence etc.

However, it should be emphasized and recalled that they were not satisfied with merely reproducing some definitions (definitiones) of their predecessors on Law, but they commented, evaluated and, sometimes, completed their ideational content, thus creating a work of "aggiornamento", that is, of enriching and updating the thesaurus of Roman classical legal thinking, hence, the sui-generis contribution of Emperor Justinian's legal experts.

Emperor Justinian's Digests (Justiniani Digestae) can, indeed, be considered "the synthesis of Roman legal thinking, systematically exposed in the form of Roman legal experts' sayings. They stated their opinion on both some principles of law, ..., and on practical or even small point issues, establishing through their sayings some classical ways of presenting the issues or problems which are called jurisprudences, that is, wise sayings of legal experts" (Floca, 1990).

As for the Justinian's Institutions (Justiniani Institutiones), which served as a Handbook for the students of the Faculties of Law in the Roman Empire (Rome, Constantinople, Beirut etc.), it should be noted that these were, in fact, the only Roman Law Handbook, which fortunately, can be handily used by law students today.

Both "Collections", i.e. Digests and Institutions, were incorporated into the most "unitary", "complete" and "representative" Collection "of Roman law and the beginnings of Byzantine law", that is, in the Juris Civilis Corpus (Floca, 1990) commanded by Emperor Justinian. 
„Jus” (Law) and „Justitia” (Justice) in Roman Solicitors' Perception and ... Nicolae V. DURĂ

The notion "Jus / ris" (Law) comes from the Latin word "justitia" (Guțu, 1983), which defines the notion of "righteousness" (Dură, 2004), "fairness", "spirit of righteousness" (Guțu, 1983), which emphasized, in fact, the applied character of the Law through a justice decision. For the Romans, justice was done through the mechanisms of this institution.

For the Roman legal experts - who created that "Jus romanum antiquum" (Old Roman Law) - "Jus (the Law) is the science (ars) of what is good and right" (Pereterskii, 1958), and "Justitia est constans et perpetua voluntas ius suum cuique tribuens" ("Justiniani Institutiones", 2002), that is, "Justice is the constant and lasting will to give to everyone what they are entitled". However, under "Jus naturale" (natural law), precisely this type of civic conduct can give to everyone what they are entitled, namely "libertas" (freedom), which was, in fact, defined by Emperor Justinian's legal experts as "... the natural capacity (naturalis facultas) of the person to do what they want, unless they are stopped by force (vi) or by law (iure)" ("Justiniani Institutiones", 2002).

In other words, "people are born free ...", but this freedom is restricted by law, as "The rules of law (juris pracepta) are - the famous Roman legal experts stated - these: live honestly (honeste vivere), not injure another (alterum non laedere) and give to each one what they are entitled to (suum cuique tribuens)" ("Justiniani Institutiones", 2002).

By the notion of "jus / ris", however, Roman legal experts referred explicitly only to "Human Law", which was different - in its content and purpose - from "Fas", that is, what "Jus vetus" (Old Roman law) said that it is "established by the Gods", and, ipso facto, by "divine law", "divine decision", hence, the phrase "fas et iura" (divine and human laws), or "fas est" "(what is allowed by the gods)" (Guțu, 1983), which imposed into the legal language of the Roman legal experts also the aphorism "summum iura, summa iuria", in the sense that "justice" which does not comply with the precepts of "Jus divinum" and of "Jus naturale" (Dură, 2014) can become "the greatest injustice" (Guțu, 1983).

\section{The distinction between "Jus" and "Lex"}

Classical Roman legal experts - among them Celsus, Ulpianus, etc. also drew a clear distinction between "Jus" (Law) and "Leges" (Laws), and used the word "jus" also in other phrases, such as, "principia iuris" (principles of law) and "iuris scientia / prudentia" (the science of law), that is "the answers of the prudents" (legal experts), which Gaius already 
considered to be "formal sources of the law" (Institutiones, LB. I, 2) (Gaius, 1982).

However, the word "jus" was used by the Romans to first designate the notion of "norm of law, and then to name it a branch of Law, such as," Jus civile" (Civil law), "Jus publicum" (Public law), "Jus gentium" (International law), "Jus praetorium" (Pretorian law), "Jus connubii" (Matrimonial law), "Jus consuetudinaris" (Common / customary law) etc.

But, the word "jus" also expressed - for the Romans - both the notion of "judgment", "court", "tribunal", in the sense of "in jus audire" (Celsus), i.e., "to bring to justice", and that of "power", "authority", which we find in the phrase "jus patris" (the authority of the parent), or in "sui juris esse" (Guţu, 1983), that is, not "under pater familias" (under the authority of the father), but it is free (independent) to do only "what is allowed (licitorum)" (Tacitus).

The classical Roman legal experts defined themselves as "sacerdotes" (priests) of the "Science of Law", because they really cultivated "justitia" (justice), revealed to people "boni et aequi notitiam" (the idea of good and fairness), distinguished "what is allowed (licitum) from what is not allowed (illicitum)". And all this with the desire "... that the good ones (bonos) be fulfilled not only out of fear of punishments (non solum metu poenarum), but also through the appeal of the reward ..." (Justinian, n.d.), hence, their conception about the educational character of the law, not just punitive (Mititelu, 2010, 2012), as it still is, unfortunately, perceived and defined by some criminal lawyers.

According to the assertion of the same Roman legal experts, this reward was, therefore, a natural consequence of doing good according to the norms of the natural moral law (Dură, 2003), and not determined by the fear of punishment, as, in fact, only in this way - the respective legal experts stated - "a true philosophy (veram philosophiam), and not to a false philosophy (simulatam filosophiam)" could be attained (Justinian, n.d.).

The famous Roman solicitors - who considered themselves the "priests" (servants) of "Jus antiquum" (Old Roman Law) - were, therefore, worthy of receiving this "reward" since they were willing to know "veram philosophiam", that is the philosophy of life according to "Jus naturale" (Natural law), "which all living beings learnt from nature (natura) ..." (Justinian, n.d.).

For some Christian legal experts of the first centuries, such as Tertullian ( $†$ 240) and Lactantius ( $†$ 325) (Dură, 2015), this "veram philosophiam" was none other than the "Gospel of Christ", which Emperor Justinian also referred to in the Prefaces of his legislation. 
„Jus” (Law) and „Justitia” (Justice) in Roman Solicitors' Perception and ... Nicolae V. DURĂ

The fact that - for the famous Roman legal experts from the 2nd 3rd centuries AD, people can be perfected, that is, become "bonos" (good) not only out of "fear of punishment", but from the desire arising "from reward" - be it only of a spiritual or religious-moral nature - it entitles us to affirm that they were, in fact, relating to the Natural moral law (Dură, 2015).

In the Byzantine Law - received and applied in the Romanian Principalities through Greek, Slavonic and Romanian Nomocanons (Codes of Laws), from the 14th - 17th centuries (Mititelu, 2014a, 2016) - this "true philosophy" was, of course, referring to the Christian moral law, which made the punishments stipulated in the Romanian Criminal Law - for different crimes (Mititelu, 2014b) - to be pronounced in the humanistic spirit of the Christian moral law.

\section{The Natural Moral Law and the Human Law}

Regarding "Jus naturale", Roman jurisprudence specified that it is "... ruled by a divine providence (divina providentia)", and, therefore, this "... remains lasting and unchanged (semper firma atque immutabilia permanent), while the laws that each city established can be changed either by the tacit consent of the population (tacito consensu populi), or by another ulterior law (vel alia postea lato)" (Justinian, n.d.).

Therefore, according to the Roman legal experts, natural law is of a divine nature, hence, its durability and unchangeability, while the laws established by each citadel - by extenso, each kin, nation or people - can be changed either by the tacit consent of the people, or by another law.

\section{The Study of Roman Law in Emperor Justinian's time}

For Romans, "consensus fecit legem", that is, consensus creates the law, and as such, by a "consensus" - even a tacit one - any law of the "Citadel-State" could be changed, and it is "its representative" - Gaius wrote - "for each people" and "is called Jus civile" (Institutiones, LB. I, I, 1).

According to the definition given by the last Handbook of Roman Law - which was kept for us - that is, "Justiniani Institutiones" (Justinian's Institutions), "the Study of (Roman) Law (Studii Juris / Romanum)" had "two branches (duae positiones): public and private (publicum et privatum). Public law refers to the organization of the Roman state", and "the private one concerns private interests" ("Justiniani Institutiones", 2002).

In Emperor Justinian's time, the study of Law (Jus/ris), therefore, offered the Law School student the opportunity to become acquainted with "Jus publicum" (Public law) and "Jus privatum" (Private law). Public law 
initiated and familiarized the student in Roman law with "the organization of the Roman state" (quod ad statum rei Romanae spectat), and Private law referred to "the public good of individuals" (quod ad sigulorum utilitatem) (Justinian, n.d.).

According to Emperor Justinian's legal experts, "Public law comprises the cult (in sacris), the priesthoods (in sacerdotibus) and the magistratures (in magistratibus)" (Justinian, n.d.), and Private law was "... of three types (tripertitum est)" ("Justiniani Institutiones", 2002), since according to Roman jurisprudence - it "draws its principles (praeceptis) from Natural law, from kins (gentium) or from Civil law (civilibus)" (Justinian, n.d.).

As for "Jus gentium", that is, the precursor of today's International law, it was - according to Gaius - the law "... which the natural reason (naturalis ratio) bestowed on all people", and which "is guarded similarly by all people, and that is why it is called - the famous Roman legal expert stated - jus gentium, as it is used by all peoples (gentes)" (Institutiones, LB. I, 1).

For the Romans from Emperor Justinian's time, Roman law was also of two types, namely, "written (ex scripto) or unwritten (self scripto), as in Greek's case (Graecos)" (Justinian, n.d.). And, according to the same legal experts, for the Romans, the "written law" (Jus scriptum) consisted also of the "law (lex), plebiscites (plebiscita), senate meetings (senatusconsulta), imperial constitutions (principum placita), magistrates' edicts (magistratum edicta), and legal experts' answers (responsa prudentium)" ('Justiniani Institutiones", 2002), that is, similar to legal expert Gaius' time (according to Institutiones, LB. I, 2-7).

It is precisely from these "laws, plebiscites, Senate meetings, emperors' constitutions, magistrates' edicts and authority of legal experts (auctoritate prudentium)" that the "the Law of the citadel", that is, "Jus civile", was in fact, founded (Papianus, Definitiones, LB. II) (Justinian, n.d.).

For the Romans there was, indeed, also a "Jus praetorianum" (Pretorian law), which is "the one that the praetors introduced - as an aid (adjuvandi), a completion or a correction of the civil law, in public's interest" (Justinian, n.d.), and about which the same Roman legal experts state that it "is also called jus honorarium, thus being named in honor of the praetors" (Justinian, n.d.). Initially, the praetor (praetor/ons) "was a magistrate", who "after $367 \mathrm{AD}$ was entrusted with civil jurisdiction", and, "after the praetorian year, the praetors become rulers of provinces" (Guțu, 1983).

From Digests we, therefore, note that "Jus" (Law) was also called "Jus honorarium" in honor of the magistrates. In fact, in Latin, by the plural form of the word "honor/ius" (honor, consideration), that is, "honores", a 
„Jus" (Law) and ,Justitia" (Justice) in Roman Solicitors' Perception and ... Nicolae V. DURĂ

"high function, dignity, honors" was designated, hence, the phrase "honores petere, adipisci", which Cicero used to mean "to exercise a magistracy" (Guțu, 1983).

In their capacity as "Magistrates", Praetors were commonly called "honores". However, in order to reach this honor and dignity, they had to go through a "cursus honores", that is, a whole "hierarchical cycle of magistratures, culminating with the consulate, which a member of the ruling class was meant to complete in his political career" (Pereterskii , 1958).

Therefore, initially, the Magistrature was perceived by the Romans as a political career. In fact, it is only much later, i.e. with the separation of powers doctrine, that one can really speak of the obligation of the magistrate (judge) to be apolitical.

For the classical Roman legal experts, this "jus honorarium" was the "living voice (viva vox) of the Civil Law (Juris civilis)" (Marcianus, LB. I a Institutions) (Justinian, n.d.), that is, the Law spoken or pronounced by the praetorian magistrates.

Regarding this act of saying, that is of pronunciation of the Law, Sabinus, a Roman legal expert from the beginning of the first century of the Christian era, wrote that, "in our State", that is, in the Roman State, "... the praetor pronounces on the right even if his decision is unfair: this (word) the famous Roman legal expert stated - refers not to what the praetor did in this way, but to what he had to do. In another sense - he adds - the place where justice is done is always right (judgment is passed)" (Pereterskii , 1958).

Therefore, according to Sabinus, the praetor pronounces "Law" (Jus) only where he pronounces the sentence (court decision), that is, in the court, hence the conclusion of the Roman legal expert according to which that place "... is rightfully called "right" (is locus recte jus appelatur)" ("Justiniani Institutiones", 2002).

According to the definition given by Roman legal experts, "the law (lex) is what the Roman people (populus Romanus) decided at the proposal of a senatorial magistrate, such as a consul" ("Justiniani Institutiones", 2002), and about the Imperial Constitutions (Sacrae Constitutiones); in "Institutiones" we are told that some were "general in character", thus being "obligatory for all", and others did not exceed "the person in question" ("Justiniani Institutiones", 2002). 


\section{The Roman Jurisprudence, "the Science of what is Wright and Wrong"}

Regarding the "Legal experts' responses" (Responsa prudentium) which helped create the famous Roman jurisprudence - these were constituted by "the decisions (sententiae) and opinions (opiniones) of those allowed to create the law (iura condere)" ("Justiniani Institutiones", 2002).

From the text of the same "Justinian Institutions" (Justiniani Institutiones) we find out that, "even from the oldest times (antiquitus), it was decided for some to interpret the laws publicly (qui iura public interpretarentur); to them the Emperor gave the right to make decisions (Jus resprudendi datum est). They were named legal experts (jurisconsulti)" (“Justiniani Institutiones", 2002).

It should also be emphasized and recalled that Emperor Justinian was the one who - at the proposal of his legal experts, led by professor Tribonian at the Faculty of Law of the University of Constantinople acknowledged on behalf of those who interpreted the laws, that is, legal experts, not only the right to express their opinions on the text of a law, that is, to interpret it, but also "jus respondendi" (the right to make decisions).

Justinian's legal experts also stated that, in his Imperial "Constitutions", he stipulated that the "decisions (sententiae) ... and the opinions (opiniones)" of the legal experts "have such an authority (auctoritatem) that the judge (iudici) is not allowed (non liceret) to deviate from their decisions (a responso eorum)" ("Justiniani Institutiones", 2002).

Over time, both these opinions, interpretations and sayings about the nature and purpose of the law, as well as the judgments or decisions taken in different cases - by these legal experts - have created a true legal doctrine, known from the time of the classical Roman legal experts (2nd $3 r d$ centuries AD) under the name of "juris-prudentia/ae", that is, precepts or sayings of the Law.

According to the classical definition, "Juris prudentia est divinarum atque humanarum rerum notitia, iusti atque inusti scientia" ("Justiniani Institutiones", 2002) (The jurisprudence is the knowledge of divine and human things, the science of what is right and wrong). In other words, this doctrine of Roman law presumed not only the knowledge of the "Divine law" and Human law, but also the possession of the science of what is right and unjust, that is, of justice and injustice.

As for "Jus divinum" (Jus divinum), Emperor Justinian's legal experts stated that, being "ruled by the divine providence (divine providence constituted), it remains always (semper) solid (firma) and unchanged 
„Jus” (Law) and „Justitia” (Justice) in Roman Solicitors' Perception and ... Nicolae V. DURĂ

(immutabilia), while the laws that each citadel (civitas) established for itself can be changed either by the tacit consent of the people (tacit consensu populi) or by another, ulterior law (postea lege lata)" ("Justiniani Institutiones", 2002).

This Law arranged by a Divine Providence was known by the Romans under the name of "naturalia iura" ("Justiniani Institutiones", 2002) (natural rights), used by "only people" (solis humanibus) (Justinian, n.d.), whereas "Jus Naturale is common to all living beings (omnibus animalibus)" (Justinian, n.d.).

Among other things, regarding the "Jus naturale", the famous legal expert Ulpianus (2nd century AD) wrote that, "... according to the Natural Law (iure naturali), all are born free (omnes liberi nascerentur)", but that "... bondage spread under the Law of the tribes (a iure gentium)" (Justinian, n.d.), that is, the Law which - according to the definition of the famous legal expert Gaius - "... the natural reason (naturalis ratio) arranged for all people (omnes homini)" (Gaius, 1982).

However, this "jus gentium" is none other than the parent of today's International law, just as the "jus civilis" of the Roman State is the predecessor of the Civil Law of the States of the world today.

The same thing can be said, however, not only about the other branches of Law (constitutional, criminal, commercial etc.), but also about their legal doctrine, which was and still is dependent on the Roman legal thinking, which the famous legal experts synthesized in their sayings or pronunciations about "Jus", "Justitia" and "Jurisprudentia", known suggestively from their time under the name of "Definitiones" (Definitions), hence the obligation of legal experts today, theoreticians and practitioners, to return "ad Fontes", that is, to the sources, as only in this way they remain a part of this treasure of legal Roman thinking, still difficult to match.

\section{Instead of Conclusions}

By resorting to these "fontes" (sources) of the "Old Roman Law" (Jus romanum antiquum) - consisting of the famous definitions of the Romanian legal experts on "Law", "Justice" (Dură, 2011a, 2011b, 2011c) and so on - we will of course be able to eliminate some serious confusions that we encounter not only in the specialized literature, but also in the everyday legal language. A striking example, in this regard, remains the terminological imprecision of the notion of "Magistrate", hence the inherent confusion between "Magistrate" (Judge) and "Prosecutor" in the Romanian specialized literature. 


\section{References}

Academia Română. (1998). Dicționar explicativ al Limbii române (DEX) [Explanatory Dictionary of the Romanian language] ( $2^{\text {nd }}$ ed.). Bucharest, Romania: Univers Enciclopedic.

Dură, N. V. (2003). Dreptul şi religia. Norme juridice şi norme religios-morale [Law and religion. Legal and religious-moral norms]. Analele Universității Ovidius. Seria: Drept și Stiințte Administrative, 1, 15-24.

Dură, N. V. (2004). Ideea de drept. „Dreptul”, „dreptatea” și „morala” [The idea of Law. "Law", "justice" and "morality"]. Analele Universităţii Ovidius. Seria: Drept și Știinţe Administrative, I, 15-46.

Dură, N. V. (2007). Dreptul canonic, disciplină de studiu în Facultăţile de Drept din prestigioase Universităti europene [Canon Law, a discipline in the Faculties of Law of prestigious European Universities]. Analele Universităţii Ovidius. Seria: Drept și Ştiinţe Administrative, 1, 328-332.

Dură, N. V. (2011a). Law and morals. Prolegomena (I). Acta Universitatis Danubius. Juridica, 2, 158-173.

Dură, N. V. (2011b). Law and morals. Prolegomena (II). Acta Universitatis Danubius. Juridica, 3, 72-84.

Dură, N. V. (2011c). Thinking of some fathers of the Ecumenical Church on the law. Christian Researches, VI, 230-245.

Dură, N. V. (2013). Loi morale, naturelle, source du Droit naturel et de la Morale chrétienne. La morale au crible des religions. Studia Arabica, XXI, 213-233.

Dură, N. V. (2014). Despre „Jus naturale”. Contribuții filosofico-juridice [On "Jus naturale". Philosophical-legal contributions]. Revista de Teologie Sfântul Apostol Andrei, XVIII(1), 39-52.

Dură, N. V. (2015). "Justitia" and "aequitas" in the perception of the Greek philosophers and of the Roman jurists. Teologia M łodych, 4, 4-9.

Floca, I. N. (1990). Drept canonic ortodox. Legislație și administrație bisericească [Orthodox canon law. Church legislation and administration]. Bucharest, Romania: Editura Institutului Biblic.

Gaius. Institutiones [Instituțiile]. Bucharest, Romania: Editura Academiei RSR.

Guțu, G. (1983). Dicționar latin-român [Latin-Romanian dictionary]. Bucharest, Romania: Științifică și Enciclopedică.

Justinian. (n.d.). Digestae. LB. I, 1, 1-7. Retrieved from https://droitromain.univgrenoble-alpes.fr/Corpus/digest.htm

Justiniani Institutiones. (2002). Bucharest, Romania: Lumina Lex.

Mititelu, C. (2010). Elements of penal law in the Romanian Nomocanons printed in the 17 th century. Dionysiana, 1, 419-430. 
„Jus” (Law) and „Justitia” (Justice) in Roman Solicitors' Perception and ... Nicolae V. DURĂ

Mititelu, C. (2012). Pravilele româneşti, tipărite, din secolul al XVII-lea. Infracțiuni şi pedepse [Romanian Code of Laws, printed, from the 17th century. Offenses and penalties]. Bucharest, Romania: Didactică şi Pedagogică.

Mititelu, C. (2014a). The Byzantine law and its reception in the Romanian Principalities. Philosophical-Theological Reviewer, 4, 33-43.

Mititelu, C. (2014b). The Nomocanons (Code of Laws) printed in the Romanian countries, in the Seventeenth Century, and their provisions of criminal law. Religion, 3, 41-57.

Mititelu, C. (2016). The legislation of emperor Justinian (527-565) and its reception in the Carpathian-Danubian-Pontic space. Analecta Cracoviensia, 48, 383-397. doi:10.15633/acr.2033

Pereterskii, I. S. (1958). Digestele lui Justinian [Justinian's Digestae]. Bucharest, Romania: Științifică. 